\title{
KEABSAHAN TRANSAKSI JUAL BELI GHARAR
}

\author{
Zahra Zahira Ramadhina \\ Program Studi Ilmu Al-Qur'an dan Tafsir \\ Sekolah Tinggi Ilmu Ushuluddin Darul Quran \\ zahrazahirar11@gmail.com \\ Rachmad Risqy Kurniawan, SEI, MM \\ Sekolah Tinggi Ilmu Ushuluddin Darul Qur'an Mulia, Bogor \\ Email: rah.rizqy@gmail.com \\ Kharisma Putri \\ Sekolah Tinggi Ilmu Ushuluddin Darul Qur'an Mulia, Bogor \\ Email : Mputputkharisma123@gmail.com
}

\begin{abstract}
This study aims to determine the validity or not of sale and purchase transactions that contain elements of gharar in them. Trading activities are done to make a profit. But in reality not all buying and selling transactions are profitable. Buying and selling gharar actually causes losses because it contains elements of fraud. This research is a library research with the method used in this research is the method of tafsir tahlili. The results of this study show that the effect of gharar on the sale and purchase transaction is to make the sale and purchase transaction invalid or fasid based on the evidence of the Qur'an Surah al-Baqarah verse 188.
\end{abstract}

\section{Keywords: Gharar, Buy-Sell}

\begin{abstract}
Abstrak: Penelitian ini bertujuan untuk mengetahui sah atau tidaknya transaksi jual beli yang mengandung unsur gharar di dalamnya. Kegiatan jual beli dilakukan untuk mendapatkan keuntungan. Namun pada kenyataannya tidak semua transaksi jual beli mendatangkan keuntungan. Jual beli gharar justru menyebabkan kerugian karena mengandung unsur penipuan. Penelitian ini merupakan penelitian kepustakaan (library research) dengan metode yang digunakan dalam penelitian ini adalah metode tafsir tahlili. Hasil penelitian ini menunjukkan bahwa pengaruh gharar terhadap transaksi jual beli adalah membuat transaksi jual beli menjadi tidak sah atau fasid berdasarkan dalil al-Quran Surah al-Baqarah ayat 188.
\end{abstract}

Kata Kunci: Gharar, Jual Beli 


\section{Pendahuluan}

Islam sebagai suatu agama tidak hanya mengatur ummatnya dalam hal ibadah atau penghambaan diri kepada Allah SWT saja. Tetapi Islam juga mengatur hubungan antar manusia diantaranya dalam lingkungan sosial, politik maupun ekonomi. Urgensi ekonomi sangatlah penting sehingga diatur oleh Allah SWT untuk menciptakan masyarakat yang sejahtera, adil, dan makmur. Ekonomi dalam Islam, didasarkan pada nilai-nilai keadilan yang harus ditegakkan, dan dijadikan sebagai prinsip pokok untuk melakukan kegiatan ekonomi. Setiap kegiatan ekonomi harus berkeadilan bagi setiap pihak sehingga tidak boleh melakukan penganiayaan, penipuan dan tidak merugikan pihak lain. ${ }^{1}$

Salah satu bentuk muamalah atau transaksi dalam ekonomi Islam adalah transaksi jual beli, hukum jual beli adalah halal, sebagaimana firman Allah SWT. dalam surah al-Baqarah ayat 275 yang artinya "Dan Allah telah menghalalkan jual beli dan mengharamkan riba".

Akan tetapi hukum ini bisa berubah karena adanya suatu illat, seperti larangan jual beli yang mengandung kesamaran atau ketidakjelasan. Kesamaran itu dapat terjadi dalam akad, harga, waktu pembayaran, atau barang yang diperjual-belikan. Jual beli yang mengandung kesamaran atau ketidakjelasan dalam istilah ekonomi Islam disebut Bai' Gharar. Dalam hal jual beli gharar, para ulama berbeda pendapat dalam menentukan hukumnya, ada yang melarang dan ada juga yang membolehkan dengan illat masing-masing. ${ }^{2}$

Berlandaskan permasalahan diatas, peneliti ingin mengkaji lebih dalam pengaruh gharar terhadap keabsahan transaksi jual beli menurut tafsir QS. Al-Baqarah Ayat 188. Penelitian ini merupakan penelitian kepustakaan (library research) dengan menggunakan literatur (kepustakaan) sebagai sumber antara lain kitab tafsir dan artikel ilmiah pendukung lainnya, metode penafsiran yang digunakan dalam penelitian ini adalah metode penafsiran tahlili (analitik). Metode penafsiran tahlili (analitik) adalah metode menafsirkan Al-Quran yang berusaha menjelaskan Al-Quran dengan menguraikan berbagai seginya dan menjelaskan apa yang dimaksudkan oleh Al-Quran.

\section{Pengertian Gharar}

Menurut bahasa arti gharar adalah al-khida (penipuan), al-khathr (pertaruhan), dan al-jahalah (ketidakjelasan), yaitu suatu tindakan yang yang di dalamnya terdapat unsur pertaruhan. Dengan demikian, jual beli gharar adalah semua jual beli yang mengandung ketidakjelasan karena tidak dapat dipastikan jumlah dan ukurannya. $^{3}$

Sedangkan secara sederhana gharar adalah ketidakpastian dalam transaksi muamalah yaitu ada sesuatu yang ingin disembunyikan oleh sebelah pihak dan menimbulkan rasa ketidakadilan ataupun merugikan pihak lain. Ibnu taimiyyah berpendapat gharar ialah hal yang meragukan antara dua perkara, dimana tidak ada yang lebih jelas atau nampak. Menurut Ibnu Qayyim gharar adalah sesuatu yang tidak

\footnotetext{
${ }^{1}$ Nadratuzzaman, Hosen, Analisis Bentuk Gharar Dalam Transaksi Ekonomi, Al-Iqtishad Al-Iqtishad: Vol. I, No. 1, Januari 2009

${ }^{2}$ Ibnu Rusyd, Bidayatul Mujtahid (terjemahan), Jakarta:Pustaka Azzam 2007

${ }^{3}$ Ghufran A. Mas"eadi, Fiqh Muamalh Kontekstual, (Jakarta: PT. Raja Grafindo

Persada, 2002), h. 133.
} 
diketahui hasilnya, dan menurut Abu Ya'la gharar adalah konsekuensi yang tidak diketahui. ${ }^{4}$

Gharar banyak dilakukan oleh pedagang pada era modern ini karena ada tuntutan untuk bersaing dan berkompetisi dalam berbisnis. Dan masyarakat banyak yang berbisnis hanya mementingkan hasil dan bukan keabsahan hukumnya. Sehingga banyak para pedagang yang menghalalkan segala cara untuk mendapatkan keuntungan sebanyak-banyaknya tanpa berpikir benar atau tidaknya.

\section{Keabsahan Transaksi Jual Beli Gharar Menurut Al-Quran Dan Hadist}

Praktik gharar dalam jual beli merupakan tindakan memakan harta orang lain dengan cara bathil. Sebagaimana telah dilarang oleh Allah SWT dalam surah alBaqarah ayat 188:

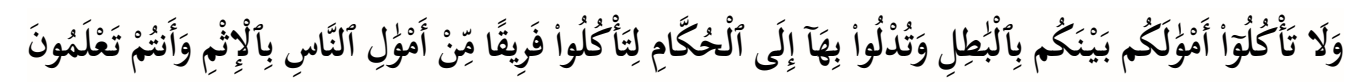

Artinya: Dan janganlah sebahagian kamu memakan harta sebahagian yang lain di antara kamu dengan jalan yang bathil dan (janganlah) kamu membawa (urusan) harta itu kepada hakim, supaya kamu dapat memakan sebahagian daripada harta benda orang lain itu dengan (jalan berbuat) dosa, padahal kamu mengetahui. Dalam Zubdatut Tafsir Min Fathil Qadir ayat ini menjelaskan bahwa transaksi jual beli harus dengan kerelaan antara kedua belah pihak tanpa adanya kecurangan, penipuan, maupun penyembunyian aib barang yang akan dijualbelikan. ${ }^{5}$

Menurut At-Thabari yang dimaksud dengan jual beli batil dalam ayat ini adalah semua transaksi yang dilarang oleh Allah SWT, ${ }^{\mathbf{6}}$ sedangkan menurut Al-Baghwy, makan secara haram itu bermacam-macam, bisa dengan merampas dan menjarah, atau bisa juga perjudian dan bisa juga dengan suap dan pengkhianatan. ${ }^{7}$

As-sa'di menafsirkan Batil dalam ayat ini adalah memakan harta orang lain secara zalim, termasuk memakannya dalam bentuk riba, mencuri dan berkhianat, dan termasuk juga mengambilnya dalam bentuk pertukaran, dengan pertukaran yang diharamkan, seperti akad riba, dan semua perjudian, karena tidak dengan pertimbangan hukum, dan termasuk juga mengambilnya karena penipuan dalam menjual, membeli, menyewa, dan sejenisnya, serta pengambilan upah mereka untuk pekerjaan yang tidak mereka lakukan tugasnya, dan ini termasuk mengambil zakat, sedekah, wakaf, dan wasiat, bagi mereka yang tidak memiliki hak dari mereka, atau di atas haknya. Semua ini dan sejenisnya, dari makan uang secara tidak adil. ${ }^{8}$

Larangan gharar secara spesifik ada dalam hadist shahih dalam kitab shahih muslim no.1513 yang diriwayatkan dari Abu Hurairah RA, Rasulullah SAW bersabda:

\footnotetext{
${ }^{4}$ Arifin, Sirajul, Gharar dan Risiko dalam Transaksi Keuangan, Jurnal TSAQAFAH Vol 6, No 2 (2010)

5 al-Asyqar, Muhammad Sulaiman, Zubdatut Tafsir Min Fathil Qadir, Riyadh: Dar Al-Moayad 1996

${ }^{6}$ Al-Ṭhabarī, Abu Ja ${ }^{e c}$ far Muhammad Ibn Jarīr Ibn Yazīd Ibn Kathir Ibn Gālib . Jāmi’u al-Bayān fī Ta`wīli al-Qur`ān (Beirut: Daarul Kitab, 1412 H/1992 M)

${ }^{7}$ Al-Baghawi, Al-Husain bin Masúd. Ma'alim al-Tanzil,. Jilid. 1. Riyad: Dar al-Taybah, 1409.

${ }^{8}$ As-Sa'di, Syaikh Abdurrahman bin Nashir. Taisirul Karimirrahman fi Tafsiri Kalamil Mannan. Cet. I; Baerut: Dar Ibn Hazm, 2003.
} 


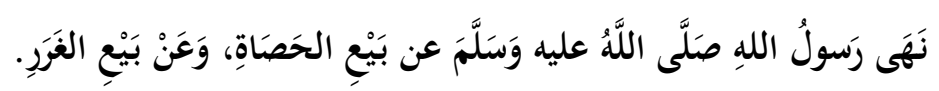

Artinya: Rasulullah telah melarang jual beli al-hashah (jual beli dengan lempar batu kecil) dan jual beli secara gharar " (H.R.Muslim). ${ }^{9}$

Berdasarkan tafsir dan hadist diatas maka dapat disimpulkan bahwa jual beli yang mengandung gharar merupakan jual beli yang diharamkan dan termasuk jual beli batil dalam surah al-Baqarah ayat 188 karena tidak adanya keridhaan antara kedua belah pihak, tidak memenuhi aspek keadilan dan kemanfaatan, adanya kecurangan, penipuan, pengkhianatan, penyembunyian aib barang yang akan dijualbelikan, serta Rasulullah telah dilarang oleh Rasulullah SAW dalam hadist shahih yang diriwayatkan oleh Muslim dari Abu Hurairah RA.

Al-Qur'an dan Hadist dengan tegas telah melarang semua transaksi bisnis yang mengandung unsur kecurangan dan ketidakjelasan. Gharar merupakan situasi dimana terjadi uncomplete information atau adanya informasi yang tidak lengkap dalam suatu transaksi. Gharar bisa terjadi bila kita mengubah sesuatu yang seharusnya bersifat pasti menjadi tidak pasti. ${ }^{10}$

Jual beli yang sifatnya gharar terbagi menjadi tiga:

1. Bila kuantitasnya banyak, hukumnya dilarang berdasarkan ijma. Seperti menjual ikan yang masih di dalam air dan menjual burung yang masih ada di udara.

2. Bila jumlahnya sedikit, hukumnya dibolehkan menurut ijma. Seperti pondasi rumah (dalam transaksi jual beli rumah).

3. Bila kuantitasnya sedang-sedang saja, hukumnya masih diperdebatkan. Namun parameter untuk mengetahui banyak sedikitnya kuantitas dikembalikan kepada kebiasaan. ${ }^{11}$

Bentuk-bentuk transaksi gharar terbagi menjadi tiga bagian, yaitu:

1. Jual beli barang yang belum ada (ma'dum)

Tidak adanya kemampuan penjual untuk menyerahkan obyek akad pada waktu terjadinya akad, baik obyek akadnya sudah ada ataupun belum ada misalnya menjual ikan yang masih ada di dalam air.

2. Jual beli barang yang tidak jelas (majhul) yaitu dalam beberapa kondisi dibawah ini:

a. Menjual sesuatu yang belum berada di bawah penguasaan penjual.

b. Tidak adanya kepastian tentang sifat tertentu dari benda yang dijual.

c. Tidak adanya kepastian tentang penyerahan obyek akad.

d. Tidak adanya kepastian obyek akad.

e. Tidak adanya jaminan kesesuaian kondisi obyek dengan yang ditentukan dalam transaksi.

3. Jual beli barang yang tidak mampu diserahterimakan, yaitu dalam kondisi sebagai berikut:

\footnotetext{
${ }^{9}$ Muslim, Abul Husain bin al-Hajjaj, Shohih Muslim, Riyadh: Dar Taybah, 2006

${ }^{10}$ Adiwarman Karim, Bank Islam: Analisis Fiqh dan Keuangan, (Jakarta: Raja Grafindo Persada, 2004), h. 31 .

${ }^{11}$ Nur, Efa Rodiah, Riba Dan Gharar: Suatu Tinjauan Hukum Dan Etika Dalam Transaksi Bisnis Modern, Al-‘Adalah Vol. XII, No. 3, Juni 2015
} 
a. Tidak adanya kepastian tentang jenis pembayaran atau jenis yang barang yang dijual

b. Tidak adanya kepastian tentang jumlah harga yang harus dibayar.

c. Tidak adanya ketegasan bentuk transaksi, yaitu adanya dua macam atau lebih transaksi yang berbeda dalam satu obyek akad tanpa menegaskan bentuk transaksi mana yang dipilih sewaktu terjadi akad.

d. Adanya keterpaksaan. ${ }^{12}$

Transaski jual beli dapat dikatakan sah atau tidaknya tergantung dari terpenuhinya rukun-rukunnya. Rukun berarti tiang atau sandaran atau unsur yang yang merupakan bagian yang tidak terpisahkan dari suatu perbuatan yang menentukan sah atau tidaknya perbuatan tersebut dan adanya atau tidak adanya sesuatu itu. ${ }^{13}$ Rukun jual beli adalah ijab qabul yang menunjukkan pertukaran barang secara ridha, baik dengan ucapan maupun perbuatan. Sehingga tanpa adanya keridhaan antara kedua belah pihak transaksi jual belinya menjadi tidak sah atau fasid. ${ }^{14}$

Sebagaimana firman Allah SWT. dalam al-Qur'an surah an-Nisa ayat 29:

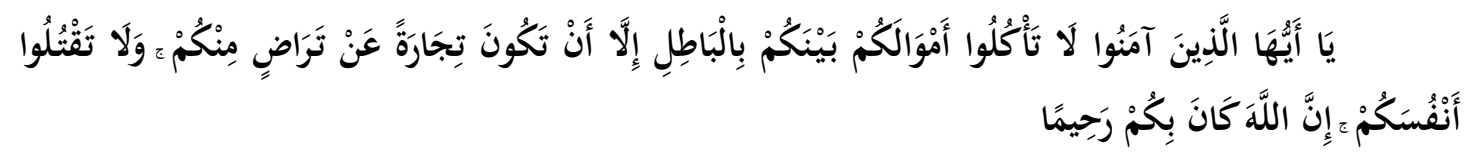

Artinya: Hai orang-orang yang beriman, janganlah kamu saling memakan harta sesamamu dengan jalan yang batil, kecuali dengan jalan perniagaan yang berlaku dengan suka sama-suka di antara kamu. Dan janganlah kamu membunuh dirimu; sesungguhnya Allah adalah Maha Penyayang kepadamu.

Ijab dan qabul dinamakan shighatul aqdi atau ucapan yang menunjukkan kepada kehendak dua belah pihak, shigatul aqdi ini memerlukan tiga syarat, yaitu:

1. Harus terang pengertiannya

2. Harus sesuai antara ijab qabul

3. Memperlihatkan kesungguhan dari pihak-pihak yang bersangkutan ${ }^{15}$

Lafadz yang dipakai untuk ijab dan qabul harus terang pengertian menurut urf (kebiasaan). Haruslah qabul itu sesuai dengan ijab dari segala segi. Apabila qabul menyalahi ijab, maka tidak sah akadnya. Kalau pihak penjual menjual sesuatu dengan harga seribu, kemudian pihak pembeli menerima dengan harga lima ratus, maka teranglah akadnya tidak sah, karena tidak ada tawaquf bainal ibaratain (penyesuaian antara dua perkataan). ${ }^{16}$ Ketidaksesuaian dalam ijab dan qobul terjadi dalam jual beli gharar , karena adanya al-khida (penipuan), al-khathr (pertaruhan), dan al-jahalah (ketidakjelasan), sehingga ada ketidaksesuaian dalam barang dan harga yang diperjualbelikan. Maka keabsahan jual beli yang mengandung gharar tidak terpenuhi

\footnotetext{
${ }^{12}$ Nadratuzzaman, Hosen, Analisis Bentuk Gharar Dalam Transaksi Ekonomi, Al-Iqtishad Al-Iqtishad: Vol. I, No. 1, Januari 2009

${ }^{13}$ Shobirin, Jual Beli Dalam Pandangan Islam, BISNIS, Vol. 3, No. 2, Desember 2015

${ }^{14}$ Abu Malik al-Kamal bin Sayyid Salim, Shahih Fiqih Sunnah, Jakarta: Pustaka Azzam, 2008

15 Tengku Muhammad Hasbi Ash Shidieqy, Pengantar Fiqih Mu'amalah, Semarang: PT. Pustaka Rizki Putra, 1997,hlm. 29

${ }^{16}$ Abdul Malik Lakibula, Pengaruh Gharar Terhadap Keabsahan Transaksi Jual Beli, Skripsi Fakultas Agama Islam Muhammadiyah Makassar, 2020.
} 
rukun ijab qobulnya sehingga tidak sah transaksinya terlebih dari itu sudah jelas dilarang dalam dalil shahih serta tidak memenuhi aspek keadilan dan kemanfaatan.

\section{Kesimpulan}

Berdasarkan penelitian diatas, jual beli yang mengandung gharar tidak sah dan termasuk jual beli batil, karena adanya al-khida (penipuan), al-khathr (pertaruhan), aljahalah (ketidakjelasan), tidak ada tawaquf bainal ibaratain (penyesuaian antara dua perkataan) antara ijab dan qobul sehingga tidak terpenuhinya rukun ijab dan qobul yaitu tidak adanya keridhaan antara kedua belah pihak, tidak memenuhi aspek keadilan dan kemanfaatan, adanya kecurangan, penipuan, pengkhianatan, penyembunyian aib barang yang akan dijualbelikan, serta Rasulullah telah dilarang oleh Rasulullah SAW dalam hadist shahih yang diriwayatkan oleh Muslim dari Abu Hurairah RA.

\section{Daftar Pustaka}

Abdul Malik Lakibula, Pengaruh Gharar Terhadap Keabsahan Transaksi Jual Beli, Skripsi Fakultas Agama Islam Muhammadiyah Makassar, 2020.

Abu Malik al-Kamal bin Sayyid Salim, Shahih Fiqih Sunnah, Jakarta: Pustaka Azzam, 2008

Adiwarman Karim, Bank Islam: Analisis Fiqh dan Keuangan, (Jakarta: Raja Grafindo Persada, 2004), h. 31.

al-Asyqar, Muhammad Sulaiman, Zubdatut Tafsir Min Fathil Qadir, Riyadh: Dar AlMoayad 1996

Al-Baghawi, Al-Husain bin Masúd. Ma'alim al-Tanzil,. Jilid. 1. Riyad: Dar al-Taybah, 1409.

Al-Ṭhabarī, Abu Jaeefar Muhammad Ibn Jarīr Ibn Yazīd Ibn Kathir Ibn Gālib . Jāmi'u al-Bayān fī Ta 'wīli al-Qur`ān (Beirut: Daarul Kitab, 1412 H/1992 M)

Arifin, Sirajul, Gharar dan Risiko dalam Transaksi Keuangan, Jurnal TSAQAFAH Vol 6, No 2 (2010)

As-Sa'di, Syaikh Abdurrahman bin Nashir. Taisirul Karimirrahman fi Tafsiri Kalamil Mannan. Cet. I; Baerut: Dar Ibn Hazm, 2003.

Ghufran A. Mas'eadi, Fiqh Muamalh Kontekstual, (Jakarta: PT. Raja Grafindo

Ibnu Rusyd, Bidayatul Mujtahid (terjemahan), Jakarta:Pustaka Azzam 2007

Muslim, Abul Husain bin al-Hajjaj, Shohih Muslim, Riyadh: Dar Taybah, 2006

Nadratuzzaman, Hosen, Analisis Bentuk Gharar Dalam Transaksi Ekonomi, AlIqtishad Al-Iqtishad: Vol. I, No. 1, Januari 2009

Nur, Efa Rodiah, Riba Dan Gharar : Suatu Tinjauan Hukum Dan Etika Dalam Transaksi Bisnis Modern, Al-'Adalah Vol. XII, No. 3, Juni 2015 
Persada, 2002), h. 133.

Shobirin, Jual Beli Dalam Pandangan Islam, BISNIS, Vol. 3, No. 2, Desember 2015

Tengku Muhammad Hasbi Ash Shidieqy, Pengantar Fiqih Mu'amalah, Semarang: PT. Pustaka Rizki Putra, 1997,hlm. 29 